\title{
Effect of Farnesyl Caffeate-Induced Apoptosis of Lung Carcinoma Cell Line from Damage to DNA
}

\author{
Kyu Sik Kim $^{1}$, Akemi Umeyama ${ }^{2}$, Toshihiro Hashimoto ${ }^{2}$, Hyun-Ju Cho ${ }^{1}$, Je-Jung Lee ${ }^{3,4}$, Masao Takei $^{3^{*}}$ \\ ${ }^{1}$ Department of Pulmonary Medicine, Chonnam National University Medical School, Gwangiu, South Korea; ${ }^{2}$ Faculty of Pharma- \\ ceutical Sciences, Tokushima University, Tokushima, Japan; ${ }^{3}$ Research Center for Cancer Immunotherapy, Chonnam National Uni- \\ versity Hwasun Hospital, Hwasun-eup, Hwasun-gun, South Korea; ${ }^{4}$ Department of Hematology-Oncology, Chonnam National Uni- \\ versity Medical School, Gwangiu, South Korea. \\ Email: *mtakei@pep.ne.jp
}

Received October $26^{\text {th }}, 2013$; revised November $27^{\text {th }}, 2013$; accepted December $12^{\text {th }}, 2013$

Copyright (C) 2013 Kyu Sik Kim et al. This is an open access article distributed under the Creative Commons Attribution License, which permits unrestricted use, distribution, and reproduction in any medium, provided the original work is properly cited.

\begin{abstract}
Farnesyl caffeate, synthesis of propolis and polar bud excretion, has been reported to exhibit anti-allergic effects in mice. However, little is known about anti-tumor effects. In this study, we investigated the effect of Farnesyl caffeate in cell proliferation of lung carcinoma cell line (H157). Antiproliferative effect and apoptosis on H157 cell were evaluated using 3-(4,5-dimethylthiazol-2-yl)-2,5-diphenyl tetrazolium bromide assay (MTT) and DNA fragmentation assay, respectively. Farnesyl caffeate inhibited the growth of H157 cell in dose-dependent manner. Morphological changes of nuclei by staining Hoechst 33258 and DNA fragmentation suggested that Farnesyl caffeate induced death involved in a mechanism of apoptosis. Moreover, caspase-3, caspase-7 and caspase-9 were activated by Farnesyl caffeate on H157 cell. The protein expressions of Bax and Bcl-2 were down-regulated by Farnesyl caffeate, resulting in cytochrome $c$ release from the mitochondria. Farnesyl caffeate significantly increased the expression of p53 proteins which indicates that p53 plays a pivotal role in the initiation phase of Farnesyl caffeate-induced HepG2 cell apoptosis. These results demonstrated Farnesyl caffeate-induced apoptosis in human lung carcinoma cell line. More detailed mechanism of Farnesyl caffeate-induced H157 apoptosis remains to be elucidated.
\end{abstract}

Keywords: Apoptosis; Propolis; Farnesyl Caffeate; DNA Fragmentation; Lung Cancer

\section{Introduction}

Various natural products have been reported to exert their anti-tumor effects by induction of cancer cell apoptosis. Propolis is a resinous substance that is collected by honeybees from plant sources and is thought to play a protective role against potential predators [1,2]. Propolis has been used in folk medicine and has been reported to possess therapeutic and prophylactic effects against inflammation, diabetes mellitus and cancer. Propolis contains up to 30 or more different flavonoid aglycones as well as a variety of phenolic compounds [3-6]. Recently, esters of cinnamic acids were identified from propolis [7]. One of these, Farnesyl caffeate has been shown by sensitizing experiments to be the main contact allergen in propolis, causing a contact dermatitis that is observed in bee-keepers and increasingly in persons using propolis preparations in "natural cures" and "biocosmetics" [8].

*Corresponding author.
Apoptosis is a genetically engineered self-destructive mechanism of cell death. It is accompanied by various morphological changes like nuclear condensation and fragmentation, isolation of cytoplasmic organelles into discrete regions, formation of surface membrane blebs and fragmentation of the dead or dying cell into membrane-bound bodies [9-11]. Apoptosis is executed by caspases, a family of intracellular aspartate-specific cysteine proteases, which amplify the apoptotic signal and proteolytically process numerous cellular target molecules with different functions [12]. A hallmark of DNA damage triggered apoptosis is reduced $\mathrm{Bcl}-2$ expression, which was followed by caspase-9/caspase-3 activation and DNA degradation. Many Bcl-2 family proteins reside the mitochondrial outer membrane. The balance between Bax and Bcl-2 determines the fate of cells in many apoptotic systems. Bcl-2 and Bcl-xL can be cleaved by caspase- 3 and cleavage of these proteins ap- 
pears to inactivate their survival function. In response to the death stimuli, the mitochondorial membranes are permeabilized, resulting in the release of cytochrome $c$. In the cytosol, cytochrome $c$ activates apoptosis by binding and activating apoptotic protease activating factor-1 (Apaf-1)-caspase-9-complex, which forms an apoptosome acting as a processing/activation center for the downstream caspase-3 [13-16]. However, the detailed antiproliferative and molecular mechanism behind the apoptosis of carcinoma cell line is not clear yet. Therefore, the present study was designed to investigate if p53 contributed to Farnesyl caffeate-induced cell apoptosis, the involvement of Bax, Bcl-xL and ERK pathway in the release of cytochrome $c$ amplified activation of caspase cascade, in promoting apoptosis in lung carcinoma cell line (H157).

\section{Materials and Methods}

\subsection{Chemicals and Reagents}

Farnesyl caffeate was dissolved in dimethyl sulfoxide (DMSO). Hoechst 33258, Ribonuclease A, MTT (3-(4,5dimethylthiazol-2-yl)-2,5-diphenyl tetrasodium bromide) and propidium iodide (PI) were purchased from Sigma Aldrich Company (St. Louis, MO). The MTT assay kit (Cell Titer 96 Aqueous One Solution Cell Proliferation Assay) was purchased from Promega Corp. (Madison, WI, USA). Polyclonal antibody against cleaved caspase3 , cleaved caspase-7 and cleaved caspase-9, and cleaved PARP, and caspase-3, caspase-7 and caspase-9, and PARP, Bcl-xL (54H6), p21, phosphor-p44/42 MAPK, and p44/42 MAP kinase were purchased from Cell Signaling Technology (Danvers, MA, USA). GAPDH (FL-335), p53 (DO-1), Bcl-2 (C-2) and Bax (2D2) antibodies were purchased from Santa Cruz (Santa Cruz, CA, USA).

\subsection{Synthesis of Farnesyl Caffeate}

Synthesis of Farnesyl caffeate was prepared as described previously [17].

\subsection{Cell Line and Cell Culture Conditions}

H157 human lung carcinoma cell were supplied by the American Type Culture Collection (Rockville, MD). Cells were maintained in RPMI 1640 (Gibco BRL, Grand Island, NY) supplemented with $10 \%$ heat-inactivated fetal bovine serum, $20 \mathrm{mM}$ HEPES ( $\mathrm{pH} 7.4)$, penicillin (100 IU/ml), streptomycin $(100 \mu \mathrm{g} / \mathrm{ml})$, and $4 \mathrm{mM}$ glutamine (Invitrogen Corp., Carlsbad, CA, USA) in a humidified atmosphere of $95 \%$ air and $5 \% \mathrm{CO}_{2}$ at $37^{\circ} \mathrm{C}$.

\subsection{Cell Growth Inhibition Test}

Growth inhibition was evaluated by MTT (Thiazolyl blue, Sigma) methods. Briefly, H157 cell (3 - $5 \times 10^{3} /$ cell $)$ seeded in 96 well plates were cultured for $24 \mathrm{~h}$, then various concentrations of HA5 were added and cultured for $24 \mathrm{~h}$. MTT test were performed to detect cell growth using an enzyme-liked imunosorbent assay (ELISA) plate reader. Each experiment was performed in six replicate wells for each drug concentration and was independently performed four times. The IC50 value was defined as the concentration needed for a $50 \%$ reduction in the absorbance, as calculated based on the survival curves.

\subsection{Cell Morphological Characteristics}

H157 cells in PRMI-1640 containing 10\% FBS were seeded into $25 \mathrm{ml}$ culture bottles and incubated overnight. $2.5-10 \mu \mathrm{M}$ of HA5 was added to the cell culture, and the cellular morphology was observed using Olympus microscope (Olympus, Japan) at $24 \mathrm{~h}$.

\subsection{Nuclear Damage Observed by Hoechst 33258 Staining}

Apoptotic nuclear morphology was assessed using Hoechst 33258 as described previously [18]. Cells were fixed with $3.7 \%$ paraformaldehyde at room temperature for $2 \mathrm{~h}$, then washed and stained with $167 \mathrm{mM}$ of Hoechst 33258 at $37^{\circ} \mathrm{C}$ for $10 \mathrm{~min}$. At the end of incubation, cells were washed and re-suspended in PBS for observation of nuclear morphology using fluorescence microscope (Olympus, Japan).

\subsection{Determination of DNA Fragmentation by Agarose Gel Electrophoresis}

DNA extraction and electrophoresis were performed as described previously [18]. Briefly, H157 cells were treated with $10 \mu \mathrm{M}$ HA-5 for 24,48 and $72 \mathrm{~h}$. The cell pellet was suspended in cell lysis buffer and kept at $4^{\circ} \mathrm{C}$ for $10 \mathrm{~min}$. The lysate was centrifuged at $12,000 \times \mathrm{g}$ for $20 \mathrm{~min}$. The supernatant was incubated with RNase a 40 $\mathrm{mg} / \mathrm{ml}$ (Sigma) at $37^{\circ} \mathrm{C}$ for $60 \mathrm{~min}$. The supernatant was mixed with $0.5 \mathrm{M} \mathrm{NaCl}$ and $50 \%$ 2-isopropanol at $-20^{\circ} \mathrm{C}$ overnight, then centrifuged at $12,000 \times \mathrm{g}$ for $20 \mathrm{~min}$. After drying, DNA was dissolved in TE buffer and separated by $2 \%$ agarose gel electrophoresis at $80 \mathrm{~V}$ for $2 \mathrm{~h}$ and stained with $0.1 \mathrm{mg} / \mathrm{ml}$ ethidium bromide. DNA fragments were visualized by ultraviolet transillumination.

\subsection{The Cell Cycle Analysis by Flow Cytometry}

After indicated treatments, cells were rinsed with icecold PBS (pH 7.4) and fixed with 70\% cold ethanol at $4^{\circ} \mathrm{C}$ for overnight. Before flow cytometric assays, cells were washed twice with ice-cold PBS and fixed cells were resuspended in PBS containing $0.1 \mathrm{mg} / \mathrm{ml}$ RNAase at room temperature for $30 \mathrm{~min}$, and then cells were 
added $50 \mu \mathrm{g} / \mathrm{ml}$ propidium iodide (Sigma-Aldrich). The stained nuclei were analyzed using a FACSCalibur (BD Biosciences, NJ, USA). At least 10,000 events were analyzed, and the percentage of cells in the sub-G1 population calculated. Aggregates of cell debris at the origin of the histogram were excluded from the sub-G1 cells. DNA histograms were created using Cell Quest TM software for Apple Macintosh (Becton Dickinson).

\subsection{Western Blotting Analysis}

H157 cells were treated with $2.5 \mu \mathrm{M}$ Farnesyl caffeate for $0,24,48$ and $72 \mathrm{~h}$. Cells were collected and frozen at $-80^{\circ} \mathrm{C}$. Western blot analysis was performed as described previously [18]. Cells were washed with PBS and lyses at $0^{\circ} \mathrm{C}$ for $30 \mathrm{~min}$ in lysis buffer $(20 \mathrm{mM}$ Hepes $(\mathrm{pH} 7.4)$ $2 \mathrm{mM}$ EGTA, $50 \mathrm{mM}$ glycerol phosphate, 1\% Triton $\mathrm{X}-100,10 \%$ glycerol, $1 \mathrm{mM}$ dithiothreitol, $1 \mathrm{mM}$ Phenylmethylsulfonyl fluoride, $10 \mathrm{~g} / \mathrm{ml}$ leupeptin, $10 \mathrm{~g} / \mathrm{ml}$ aprotinin, $1 \mathrm{mM} \mathrm{Na} \mathrm{VO}_{4}$, and $5 \mathrm{mM} \mathrm{NaF}$ ). Equal amounts of protein were separated by $6 \%-15 \%$ SDSPAGE followed by electrotransfer onto a polyvinylidene difluoride membrane (Millipore, Bedford, MA, USA). The membranes were blocked for $4 \mathrm{~h}$ with TBS-T (10 $\mathrm{mM}$ Tris-HCl, $150 \mathrm{mM} \mathrm{NaCl}$ and $0.1 \%$ Tween-20) containing 5\% nonfat milk and then incubated at room temperature with primary antibodies. The blots were washed four times for $15 \mathrm{~min}$ with $0.1 \%$ Tween 20 -containing TBS-T and then incubated for $1 \mathrm{~h}$ with peroxidase-conjugated secondary antibodies (1:5000, Jackson Immuno Research Inc., West Grove, PA, USA). After three more washes, proteins were detected by chemiluminescence detection system (iNtRON Biotech, Seoul, Korea) and the images were obtained with LAS-4000 mini (Fuji, Tokyo, Japan).

\subsection{Statistical Analysis}

Statistical analysis of the results was performed by ANOVA. Differences were considered statistically significant then $p$ values were less than 0.05 .

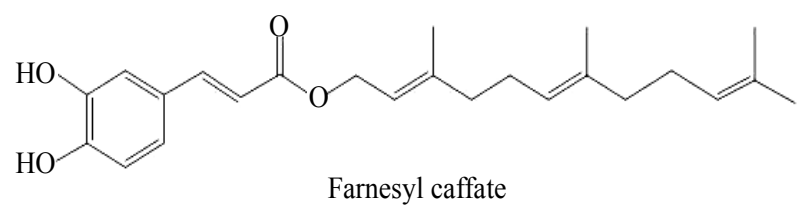

\section{Results}

\subsection{Farnesyl Caffeate Induces Apoptotic Cell Death in H157 Cells}

To determine whether Farnesyl caffeate-induced H157 cell death was caused by apoptosis, we examined the morphological changes and DNA fragmentation. We observed a decrease in the total number of cells and an accumulation of cells floating in the culture medium after $24 \mathrm{~h}$ treatment with $0.5-20 \mu \mathrm{M}$ of Farnesyl caffeate, indicating Farnesyl caffeate-induced cell death in dosedependent manner (Figure 1). Nuclear morphological changes were also observed by Hoechst 33,258 staining. In contrast, $\mathrm{H} 157$ cell in control were round in shape and stained homogeneously. After $24 \mathrm{~h}$ treatment with 2.5 $10 \mu \mathrm{M}$ of Farnesyl caffeate, blabbing nuclei and granular apoptotic bodies appeared (Figure 2). DNA fragmentation appeared obviously after $2.5-10 \mu \mathrm{M}$ of Farnesyl caffeate treatment for $24 \mathrm{~h}$ on agarose gel electrophoresis (Figure 3(a)). To determine whether the decrease in cell viability was attributable to apoptosis, cells were stained with FITC conjugated Annexin V plus PI and evaluated by FACS (Figure 3(b)). Cell underwent apoptotic cell death in response to Farnesyl caffeate.

\subsection{Caspases Activation Relevant to Farnesyl Caffeate-Induced H157 Cell Death}

Western blot analysis was performed to confirm the participation of caspase-3, caspase-7 and caspase-9. The 17 $\mathrm{kDa}$ and $19 \mathrm{kDa}$ band of caspase- 3 were degraded after 48 - $72 \mathrm{~h}$ treatment with Farnesyl caffeate $25 \mu \mathrm{M}$ (Figure 4). Similar results were also obtained with caspase-7 and caspase-9 (Figure 4). The characteristic associated with the execution phase of the apoptosis pathway is the specific PARP cleavage by caspases. This cleavage leads to inactivation of the enzyme, thus preventing futile DNA repair cycles. It has been reported that capase-3 is the most efficient processing enzyme for PARP. Cleavage of PARP was examined after treatment with Farnesyl caffeate. As expected, the amount of the $89 \mathrm{kDa}$ degraded product increased after $48-72 \mathrm{~h}$ treatment with Farnesyl caffeate (Figure 4). These results indicate that caspase-3 is activated in Farnesyl caffeate induced apoptosis in H157 cell.

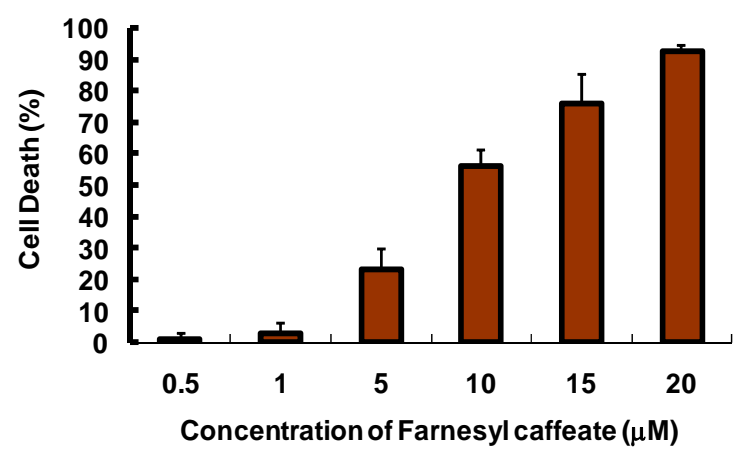

Figure 1. Effect of apoptosis induced by Farnesyl caffeate on lung carcinoma cell line (H157). H157 cell were treated Farnesyl caffeate at various concentrations for $24 \mathrm{~h}$. Cell viability was measured by MTT assay. Data are the mean \pm S.E.M. of four independent experiments. 


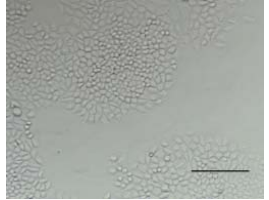

Control

Hoechst 33258 stainig

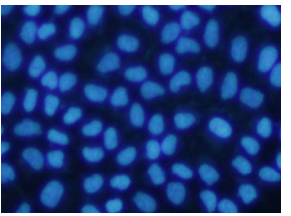

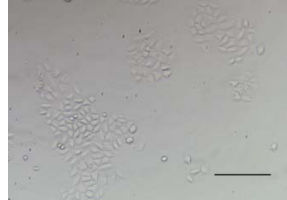

HA5 $(2.5 \mu \mathrm{M})$

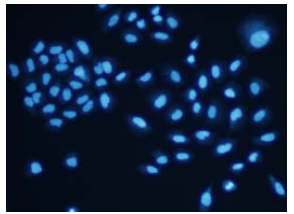

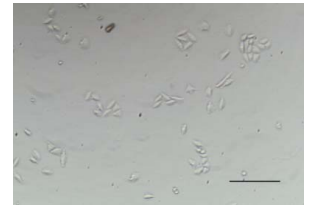

HA5 $(5 \mu \mathrm{M})$

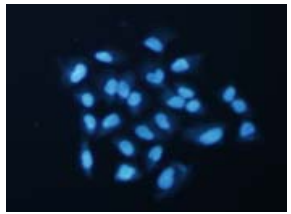

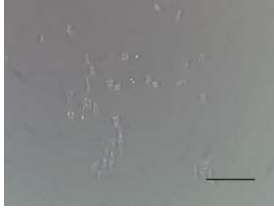

HA5 $(10 \mu \mathrm{M})$

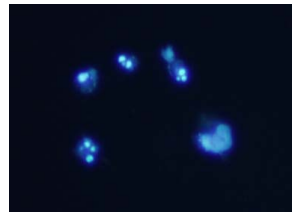

Figure 2. Morphological changes of $\mathrm{H157}$ cell by phase contrast and fluorescence microscope. H157 cell were treated with 2.5 - $10 \mu \mathrm{M}$ Farnesyl caffeate for $24 \mathrm{~h}$.

\subsection{Cytochrome $c$ Release Following Altered Bax/Bcl-xL and Bax/Bcl-2 Expression in Farnesyl Caffeate-Treated H157 Cells}

The Bcl-2 family members are critical regulators of the mitochondrial pathway that induces intrinsic activation of caspases. To confirm whether such a mechanisms is involved in Farnesyl caffeate induced apoptosis, H157 cells were incubated with Farnesyl caffeate $25 \mu \mathrm{M}$ for 24, 48 and $72 \mathrm{~h}$. At 72 h, after treatment with Farnesyl caffeate the expression of Bcl-2 and Bcl-xL began to decrease, whereas that of Bax increased slightly (Figure 5). These observations seem that protein expression of ration of Bcl-xL/Bax and Bcl-2/Bax was down-regulated and Farnesyl caffeate-induced apoptosis involves the initial phase mediated by the balance among Bcl-xL, Bcl-2 and Bax proteins, resulting in cytochrome $c$ release from the mitochondria.

\subsection{Accumulation of p53 and Down Regulation of ERK in Farnesyl Caffeate-Induced Apoptosis}

To ascertain whether p53 and ERK is required in Farnesyl caffeate-induced cell apoptosis, H157 cell were treated with Farnesyl caffeate at $25 \mu \mathrm{M}$ for 24,48 and 72 $\mathrm{h}$. The expression of p53 increased at $48 \mathrm{~h}$ and $72 \mathrm{~h}$. The expression of p53 increased at $24 \mathrm{~h}$ and then these expressions declined at $48-72 \mathrm{~h}$ gradually. In contrast, the expression of ERK1/2 increased at $24 \mathrm{~h}$ and then markedly decreased at $72 \mathrm{~h}$ (Figure 6). The results suggest that ERK and p53 activation were required for Farnesyl caffeate-induced apoptotic pathway.

\section{Discussion}

In this study, we showed that Farnesyl caffeate inhibited the growth of lung carcinoma cell line (H157) in dosedependent manner. Morphological changes of nuclei by staining Hoechst 33258 and DNA fragmentation suggested that Farnesyl caffeate-induced H157 cell death involved in a mechanism of apoptosis. MTT assay suggested significant antiproliferative effect of Farnesyl caffeate varied depending on the cell line. Further understanding the mechanism behind the Farnesyl caffeateinduced apoptosis in lung carcinoma cells promotes this compound as a valid anti-cancer agent. Farnesyl caffeate treated cells displayed characteristic ladder-like patterns compared to untreated cells. Further flow cytometric analysis indicated decreased relative size and increased internal complexity in the treated cells indicating apoptosis.

PAPR (116-kDa), a DNA repair enzyme, is probably best characterized caspase substrate, which is cleaved during apoptosis to a $24-\mathrm{kDa}$ and a $85-\mathrm{kDa}$ fragment representing the N-terminal DNA-binding domain and the C-terminal catalytic subunit, respectively. During apoptosis, PARP is selectively cleaved by several caspases, especially by caspase-3 [19]. Detection of an $85-\mathrm{kDa}$ or 24-kDa caspase cleavage fragment of PAPR was shown to be a hallmark of apoptosis. In this study, the bands of procaspase-3 were degraded after Farnesyl caffeate administration, followed by the degradation of caspase- 3 substrates, PARP minor 85-kDa fragment was increased. The activation of caspase- 3 and PAPR cleavage were associated in the Farnesyl caffeate-induced apoptosis similar to the apoptosis reported in some anti-cancer drugs [20]. It seems that the expression of caspase-7 and caspase-9 would be essential to further understand the exact role of caspase's in the Farnesyl caffeate-induced apoptosis. These results suggest that the caspase cascade plays a critical role in Farnesyl caffeate-mediated H157 cell line apoptosis.

The extracellular signal regulated kinase is an important mediator of signal transduction processes that serve to coordinate the cellular responses to a variety of extracellular stimuli [16]. We showed that the expression of 


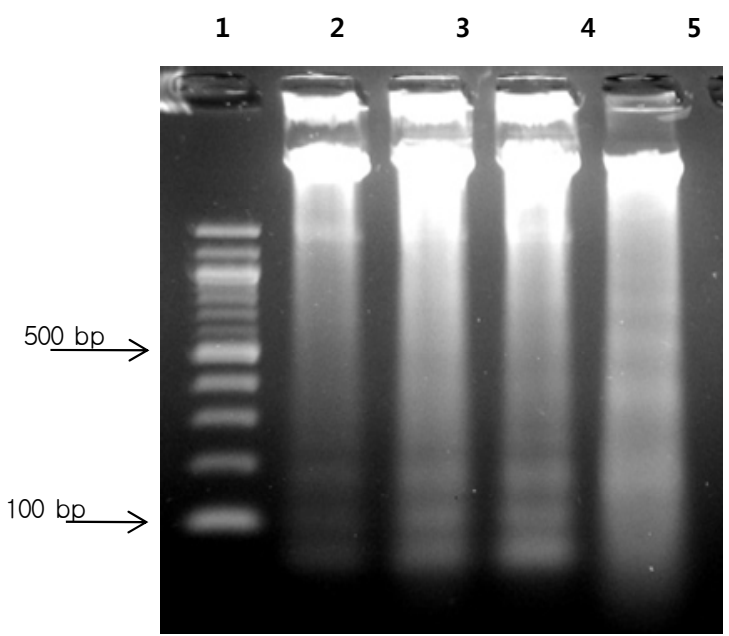

$$
\begin{array}{ll}
\text { 1. } & \text { 100bp DNA marker } \\
\text { 2. } & \text { H157 control } \\
\text { 3. } & \text { H157 HA5 }(2.5 \mu \mathrm{M}) \\
\text { 4. } & \text { H157 HA5 }(5 \mu \mathrm{M}) \\
\text { 5. } & \text { H157 HA5 }(10 \mu \mathrm{M})
\end{array}
$$

(a)

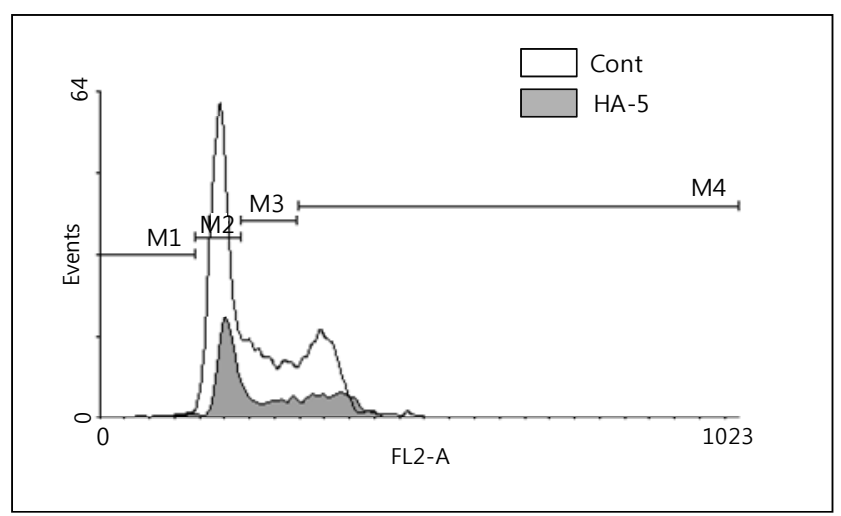

\begin{tabular}{|c|c|c|c|c|}
\hline & sub G0/G1 & G1 & S & G2/M \\
\hline cont & 0.86 & 50.11 & 24.16 & 25.41 \\
\hline HA5 & 3.48 & 42.77 & 22.65 & 31.99 \\
\hline
\end{tabular}

H157 cell cycle

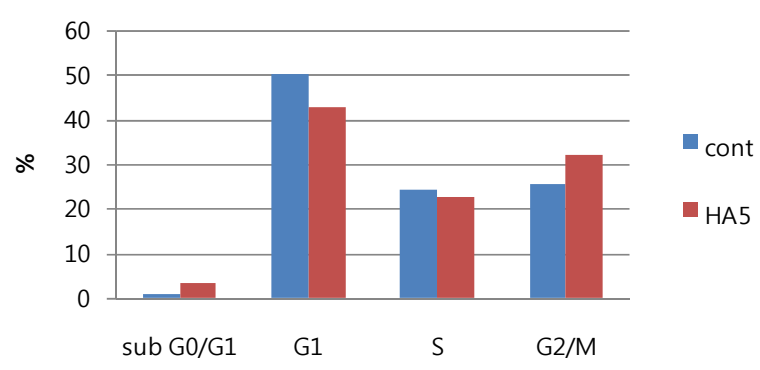

(b)

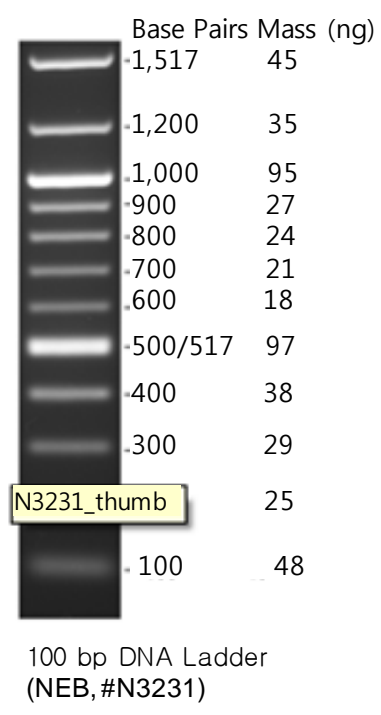

BD calibur

software : WinMDI

Figure 3. Farnesyl caffeate induced DNA fragmentation in $\mathrm{H} 157$ cell. (a) Cells were cultured with different concentrations of Farnesyl caffeate for $24 \mathrm{~h}$; (b) Cells were treated with $10 \mu \mathrm{M}$ Farnesyl caffeate for $24 \mathrm{~h}$, at which point they were fixed and stained with prodium iodide. 


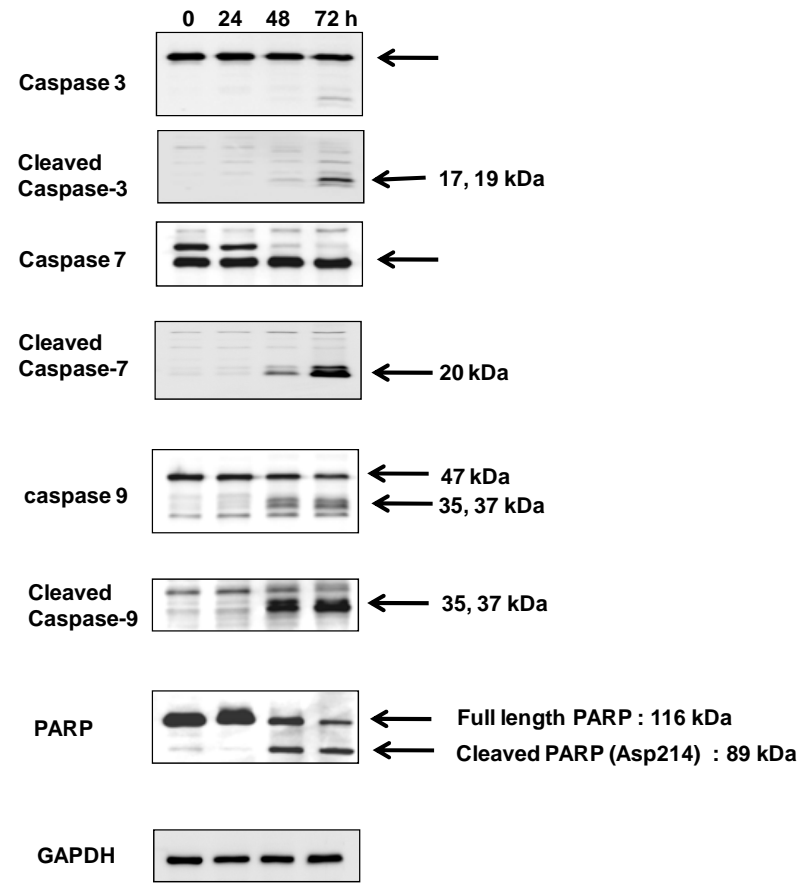

Figure 4. Degradation of caspase-3, caspase-7 and caspase-9, and PAPR in Farnesyl caffeate-treated $\mathrm{H157}$ cell. Cells were treated with $2.5 \mu \mathrm{M}$ Farnesyl caffeate for the indicated times. Caspase-3, caspase-7 and caspase-9, and PARP were detected using Western blot analysis.

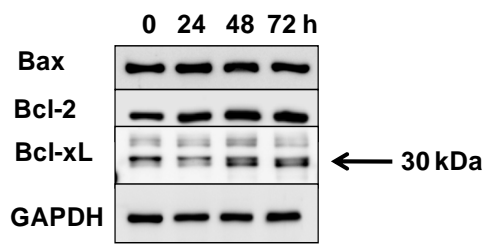

Figure 5. Different expression of Bax, Bcl-2 and Bcl-xL in Farnesyl caffeate-treated $\mathrm{H} 157$ cell. Cells were treated with $2.5 \mu \mathrm{M}$ Farnesyl caffeate for indicated times, and the protein bands were detected by Western blot analysis.

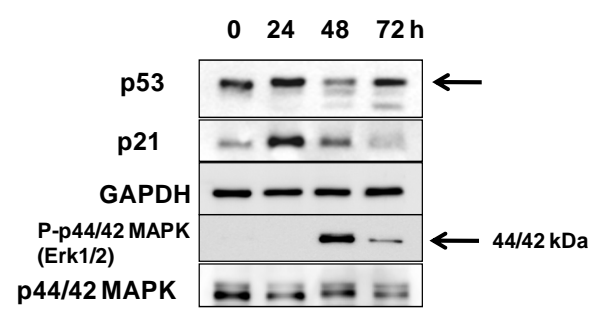

Figure 6. Expression of p53 and ERK2 in Farnesyl caffeatetreated $\mathrm{H} 157$ cells. Cells were incubated with $2.5 \mu \mathrm{M}$ Farnesyl caffeate for indicated times. P53 and ERK2 were detected using Western blot analysis.

p53 was reduced, suggesting Farnesyl caffeate-induced apoptosis through activation of $\mathrm{p} 53$ in response to DNA damage.

Several pro-apoptotic proteins, such as Bax and Bak, translocate to the mitochondrial membrane, and this localization is associated with their pro-apoptotic activities. It has been reported that $\mathrm{Bcl}-2$ could exert its action through heterodimerization with Bax. Bcl-2 and Bcl-xL are cleaved by caspase- 3 , and are converted to proapoptotic protein similar to Bax. Therefore, the ratio between Bcl-2 and Bax or Bcl-xL and Bax is a decisive factor to activate cell death [21-25]. H157 cell treated with Farnesyl caffeate exhibited the elevated ration between pro-apoptotic $\mathrm{Bax}$ and anti-apoptotic $\mathrm{Bcl}-2$ or $\mathrm{Bcl}-\mathrm{xL}$. The oligomerization of $\mathrm{Bax}$ in the mitochondrial membrane has been shown to induce cytochrome $c$ release, meanwhile pro-apoptotic Bcl-2 cleavage product was reported to localize on mitochondrial membrane and caused release of cytochrome $c$ [26-28]. In this study, the protein expression of cytochrome $c$ was markedly up regulated followed by the changes of $\mathrm{Bcl}-2 / \mathrm{Bax}$ and $\mathrm{Bcl}-$ $\mathrm{xL} / \mathrm{Bax}$ ratios in $\mathrm{H} 157$ cell treated by Farnesyl caffeate. These results suggested that the mitochondrial pathway of cell death, including Bcl-2 family and cytochrome $c$, might be involved in $\mathrm{H} 157$ cell death and orchestrates the caspase cascades.

We demonstrated that Farnesyl caffeate-induced apoptosis in $\mathrm{H} 157$ cell via accumulation of $\mathrm{p} 53$, alters the Bax/Bcl-2 ration, and activates caspases, resulting in cytochrome $c$ release from the mitochondria. More detailed mechanism of Farnesyl caffeate-induced human lung carcinoma cell apoptosis remains to be elucidated.

\section{REFERENCES}

[1] E. L. Ghisalberti, "Propolis: A Review," BEE World, Vol. 60 , No. 2, 1979, pp. 59-84.

[2] W. Greenaway, et al., "The Analysis of Bud Exudates of Populus Euramericana and of Propolis by Gaschromatograph-Mass Spectrometry," Proceedings of the Royal Society of London, Vol. 232, 1987, pp. 249-272. http://dx.doi.org/10.1098/rspb.1987.0073

[3] E. M. Schneidewind, et al., "Zur Kenntnis der Inhaltsstoffe von Propolis," Pharmazie, Vol. 30, 1975, p. 803.

[4] E. Wollenweber, "Flavonoidmuster als Systematisches Merkmal in der Gattung Populus," Biochemical Systematics and Ecology, Vol. 3, No. 1, 1975, pp. 35-45. http://dx.doi.org/10.1016/0305-1978(75)90039-3

[5] M. Vanhaelen, "Propolis: Origin, Microscopic Investigations, Chemical Constituents and Therapeutical Activity," Journal de Pharmacie de Belgique, Vol. 34, 1979, pp. 253-259.

[6] E. Wollenweber, et al., "A Novel Caffeic Acid Derivate and Other Constitutents of Propolis Bud Excretion and Propolis (Bee-Glue)," Zeitschrift für Naturforschung, Vol. 42, 1987, pp. 1030-1034.

[7] E. Schneidewind, et al., "Identigizierung Eines aus Propolis Isolierten Antimirobiell Wirksamen Inhaltsstoffes," Pharmazie, Vol. 34, No. 2, 1979, pp. 103-106. 
[8] B. M. Hausen, et al., "Propolis Allergy I. Origin, Properties Usage and Literature Review," Contact Dermatitis, Vol. 17, No. 3, 1987, pp. 163-170. http://dx.doi.org/10.1111/j.1600-0536.1987.tb02699.x

[9] P. A. Hill, et al., "Multiple Extracellular Signals Promote Osteoblast Survival and Apoptosis," Endocrinology, Vol. 138, No. 9, 1997, pp. 3849-3858. http://dx.doi.org/10.1210/en.138.9.3849

[10] N. Kawazoe, et al., "Tiam1 Is Involved in the Regulation of Bufalin-Induced Apoptosis in Human Leukemia Cells," Oncogene, Vol. 18, No. 15, 1999, pp. 2413-2421. http://dx.doi.org/10.1038/sj.onc.1202555

[11] S. Mizukami, et al., "Imaging of Caspase-3 Activation in HeLa Cells Stimulated with Etoposide Using a Novel Fluorescent Probe," FEBS Letters, Vol. 453, No. 3, 1999, pp. 356-360. http://dx.doi.org/10.1016/S0014-5793(99)00755-3

[12] G. M. Cohen, "Caspase: The Executioners of Apoptosis," Biochemical Journal, Vol. 326, No. 5693, 1997, pp. 1-16.

[13] S. Nagata, "Apoptosis by Death Factor," Cell, Vol. 88, No. 3, 1997, pp. 355-365. http://dx.doi.org/10.1016/S0092-8674(00)81874-7

[14] G. R. Green and J. C. Reed, "Mitochondria and Apoptosis," Science, Vol. 281, No. 5381, 1998, pp. 1309-1312. http://dx.doi.org/10.1126/science.281.5381.1309

[15] L. Y. Li, X. Luo and X. Wang, "Endonuclease G Is an Apoptotic DNase When Released from Mitochondria," Nature, Vol. 412, No. 6842, 2001, pp. 95-99. http://dx.doi.org/10.1038/35083620

[16] J. Klefstrom, et al., "c-Myc Augments the Apoptotic Activity of Cytosolic Death Receptor Signaling Proteins by Engaging the Mitochondrial Apoptotic Pathway," The Journal of Biological Chemistry, Vol. 277, No. 45, 2002, pp. 43224-43232. http://dx.doi.org/10.1074/jbc.M206967200

[17] T. Hashimoto, et al., "Synthesis of Two Allergenic Constituents of Propolis and Poplar Bud Excretion," Zeitschrift für Naturforschung, Vol. 43, No. 5-6, 1998, pp. 470-472.

[18] M. Zhao, et al., "The Course of Uncarinic Acid-E-Induced Apoptosis of HepG2 Cells from Damage to DNA and p53 Activation to Mitochondrial Release of Cytochrome c," Biological \& Pharmaceutical Bulletin, Vol. 29, No. 8, 2006, pp. 1639-1644.

\section{Abbreviations}

Bax: Bcl-2-associated X protein, MTT: 3-(4,5-di-methylthiazol-2-yl)-2,5-diphenyltetrazolium bromide, yel- http://dx.doi.org/10.1248/bpb.29.1639

[19] S. H. Kaufmann, et al., "Specific Proteolytic Cleavage of Poly (ADP-Ribose) Polymerase: An Early Marker of Chemotherapy-Induced Apoptosis," Cancer Research, Vol. 53, No. 17, 1993, pp. 3976-3985.

[20] Y. K. Park, et al., "Antimicrobial Activity of Propolis on Oral Microorganisms," Current Microbiology, Vol. 36, No. 1, 1998, pp. 24-28. http://dx.doi.org/10.1007/s002849900274

[21] X. M. Yin, et al., "BH1 and BH2 Domains of Bcl-2 Are Required for Inhibition of Apoptosis and Heterodimerization with Bax," Nature, Vol. 369, No. 6478, 1994, pp. 321-323. http://dx.doi.org/10.1038/369321a0

[22] E. H. Cheng, et al., "Bax-Independent Inhibition of Apoptosis by Bcl-XL," Nature, Vol. 379, No. 6565, 1996, pp. 554-556. http://dx.doi.org/10.1038/379554a0

[23] J. C. Reed, "Double Identity for Proteins of the Bcl-2 Family," Nature, Vol. 387, No. 6635, 1997, pp. 773-776. http://dx.doi.org/10.1038/42867

[24] L. M. Adams and S. Cory, "The Bcl-2 Protein Family Arbiters of Cells Survival," Science, Vol. 281, No. 5381, 1998, pp. 1322-1326.

http://dx.doi.org/10.1126/science.281.5381.1322

[25] D. G. Kirsch, et al., "Caspase-3-Dependent Cleavage of Bcl-2 Promotes Release of Cytochrom c," The Journal of Biological Chemistry, Vol. 274, No. 30, 1999, pp. 2115521161. http://dx.doi.org/10.1074/jbc.274.30.21155

[26] R. M. Kluck, et al., "The Release of Cytochrome $c$ from Mitochondria: A Rimary Site for Bcl-2 Regulation of Apoptosis," Science, Vol. 275, No. 5303, 1997, pp. 11321136. http://dx.doi.org/10.1126/science.275.5303.1132

[27] J. Yang, et al., "Prevention of Apoptosis by Bcl-2: Release of Cytochrome $c$ from Mitochondria Blocked," Science, Vol. 275, No. 5303, 1997, pp. 1129-1132. http://dx.doi.org/10.1126/science.275.5303.1129

[28] N. S. Wang, et al., "Transient Expression of Wild-Type or Mitochondrially Targeted Bcl-2 Induces Apoptosis, Whereas Transient Expression of Endoplasmic Reticulum-Targeted Bcl-2 Is Protective against Bax-Induced Cell Death," The Journal of Biological Chemistry, Vol. 276, No. 47, 2001, pp. 44117-44128. http://dx.doi.org/10.1074/jbc.M101958200

low tetrazole, Bcl-2:B-cell lymphoma 2, PARP: poly (ADP-ribose)polymerase, FITC: fluorescein isothiocyanate. 